\title{
OCENA ZACHOWAŃ ŻYWIENIOWYCH CHORYCH NA NOWOTWÓR
}

\author{
ASSESSMENT OF CANCER PATIENTS' EATING HABITS \\ Olga Dąbska', Ewa Humeniuk¹, Katarzyna Pawlikowska-Łagód², Małgorzata Matuska \\ ${ }^{1}$ Zakład Patologii i Rehabilitacji Mowy, Wydział Nauk o Zdrowiu \\ Uniwersytet Medyczny w Lublinie \\ ${ }^{2}$ Zakład Etyki i Filozofii Człowieka, Wydział Nauk o Zdrowiu \\ Uniwersytet Medyczny w Lublinie
}

DOI: https://doi.org/10.20883/pielpol.2018.6

\section{STRESZCZENIE}

Wstęp. Choroby nowotworowe stanowią drugą po chorobach układu krążenia przyczynę zgonów w społeczeństwie polskim. Wielu autorów donosi, iż tzw. niehigieniczny styl życia, zwłaszcza zaś nieprawidłowy sposób odżywiania, może indukować wystąpienie chorób nowotworowych.

Cel. Ocena zachowań zdrowotnych dotyczących przestrzegania zaleceń dietetycznych chorych na nowotwór w odniesieniu do czynników socjalnych i demograficznych.

Materiał i metoda. Grupę badaną stanowiło 100 osób chorych na nowotwór. Posłużono się metodą sondażu diagnostycznego, techniką ankietową. Wykorzystano wybrane pytania Inwentarza Zachowań Zdrowotnych (IZZ) Zygfryda Juczyńskiego zaliczane do kategorii Prawidłowe Nawyki Żywieniowe (PNŻ) i autorską ankietę badającą regularność odżywiania wśród pacjentów onkologicznych. Analizy materiału badawczego dokonano przy użyciu pakietu statystycznego STATISTICA 12 i programu Microsoft Office Excel. Przyjęto poziom istotności p < 0,05, wskazujący na istotne statystycznie różnice bądź zależności.

Wyniki. Ankietowani posilali się przeważnie 3-4 razy dziennie (53\%). Zalecaną przez IZZ liczbę 5 posiłków deklarowało 35\% badanych. Badania nie wykazały istotnego związku między liczbą dziennie konsumowanych posiłków a zmiennymi socjodemograficznymi i typem nowotworu, czasem trwania oraz rozpoznania choroby. W ogólnej ocenie analizowana próba uzyskała przeciętne rezultaty w kategorii Prawidłowe Nawyki Żywieniowe $(3,36)$. Ankietowani deklarowali najlepsze zachowania żywieniowe wobec unikania spożycia soli $(3,44)$, wobec konsumpcji dużej ilości warzyw i owoców $(3,41)$, a także wobec dbania o prawidłowe odżywianie $(3,38)$.

Wnioski. Mimo nasilającego się społecznego przekonania, że dbanie o kondycję zdrowotną jest ważne, deklaracje osób z chorobą nowotworową dotyczące troski o stan własnego zdrowia nie korelują dodatnio z praktykami zdrowotnymi.

SŁOWA KLUCZOWE: odżywianie, dieta, nowotwór, styl życia, zachowania zdrowotne.

\section{Wprowadzenie}

Choroby nowotworowe stanowią drugą po chorobach układu krążenia przyczynę zgonów w społeczeństwie

\begin{abstract}
Introduction. Cancer is the second cause of death, after cardiovascular diseases, among Polish people. Many authors claim that the unhygienic lifestyle as well as improper diet can lead to cancer. Aim. Assessment of diets among cancer patients in regards to socio-demographic factors.

Material and methods. The research was conducted on the group of 100 cancer patients. A diagnostic poll method a surey technique was used when conducting this study. Selected questions from the Health Behavior Inventory (HBI) by Zygfryd Juczyński belonging to the Proper Eating Habits (PEH) category were used. The authorial survey assessing regularity of nutrition among cancer patients was used, as well. STATISTICA 12 and Microsoft Office Excel were used to analyze the gathered data. Statistical significance of $p<0,05$ was assumed which indicated statistically important differences or correlations.

Results. Most of the surveyed (53\%) consumed food 3-4 times a day. $35 \%$ of the surveyed ate five meals a day as recommended by the HBI. The survey did not show any correlation between the number of meals per day and socio-demographic factors, type of cancer, time of diagnosis and illness duration. In general assessment the surveyed got an average score regarding the Proper Eating Habits category (3.36). Avoidance of salt (3.44), eating a lot of fruit and vegetables (3.41) and focusing on the proper diet (3.38) were the best proper eating habits cultivated by the surveyed.

Conclusions. Despite the widespread belief that taking care of one's health is important, people's with cancer declarations regarding their own health do not correlate with the health practices that should be undertaken by them.
\end{abstract}

KEYWORDS: nutrition, diet, cancer, lifestyle, health behavior.

polskim. Liczba zachorowań na nowotwory w Polsce na przestrzeni ostatnich lat systematycznie wzrasta. Wielu autorów donosi, iż tzw. niehigieniczny styl życia, zwłasz- 
cza zaś nieprawidłowy sposób odżywiania, może indukować wystąpienie chorób nowotworowych. Światowa Fundacja Badań nad Rakiem (ang. World Cancer Research Fund) i Amerykański Instytut Badań nad Rakiem (ang. American Institute for Cancer Research) wśród głównych czynników zapobiegających rozwojowi nowotworów wymieniają podejmowanie ruchu, odpowiednią masę ciała, przestrzeganie zaleceń dietetycznych [1]. Zachowania prozdrowotne zapobiegają wielu chorobom, pomagają w ich leczeniu i zmniejszają prawdopodobieństwo nawrotu [2]. „Leczenie pacjentów z chorobą nowotworową obejmuje nie tylko odpowiednią terapię farmakologiczną, rehabilitacyjną, psychologiczną, ale także dietetyczną, mającą na celu przeciwdziałanie procesowi wyniszczenia nowotworowego" [3].

Światowa Fundacja Badań nad Rakiem uznała nieprawidłowe nawyki żywieniowe za dziesięciokrotnie bardziej istotny czynnik etiologiczny chorób nowotworowych niżeli pozostałe determinanty [1]. Ponadto nieprzestrzeganie zaleceń dietetycznych zaraz po paleniu tytoniu stanowi drugą przyczynę chorób nowotworowych u 20 milionów ludzi [4]. Szacuje się, iż 40-60\% przypadków nowotworów związanych jest z żywnością oraz żywieniem [5], a dietozależne nowotwory to nie tylko te zlokalizowane w obrębie układu pokarmowego [6]. „Do tych nowotworów zalicza się m.in. nowotwór piersi, jelita grubego, przełyku, żołądka i trzustki”, rak endometrium i nerki [7].

\section{Cel pracy}

Celem niniejszej pracy była ocena zachowań zdrowotnych dotyczących przestrzegania zaleceń dietetycznych chorych na nowotwór w odniesieniu do czynników socjalnych i demograficznych.

\section{Materiał i metody}

Grupę badaną stanowiło 100 osób chorych na nowotwór w wieku 21-72 lat, przy czym średnia wieku wyniosła 46,22 $\pm 12,80$ roku. Zdecydowana większość analizowanej próby (69\%) to kobiety i mieszkańcy miast (66\%). Niespełna połowa badanych była w związku małżeńskim (45\%). W badanej grupie dominowały osoby z średnim (49\%) i zawodowym (31\%) wykształceniem. W samoocenie badanych sytuacja materialna została określona zazwyczaj jako dobra (57\%). Niespełna połowa ankietowanych chorowała na nowotwór złośliwy (48\%). Średni czas trwania choroby wynosił 2,17 $\pm 1,81$ roku (zakres od 2 miesięcy do 10 lat). U przeważającej większości badanych (85\%) nowotwór rozpoznano po raz pierwszy i nie występowały choroby współistniejące (79\%). Ankietowani nie byli przeważnie obciążeni chorobą nowotworową w wywiadzie rodzinnym (72\%).
Badani chorowali na nowotwór piersi (34\%), płuc (13\%), macicy (11\%), jelita grubego (8\%), odbytu (7\%), tarczycy $(6 \%)$, jądra (5\%), jajnika (3\%), jelita cienkiego (3\%), nerek (3\%), układu chłonnego (3\%) i inne.

Badanie wykonano metodą sondażu diagnostycznego, techniką ankietową. Narzędziem badawczym była autorska ankieta badająca regularność odżywiania wśród pacjentów onkologicznych. Narzędzie składało się z pytań zamkniętych jednokrotnego wyboru. Wykorzystano także wybrane pytania Inwentarza Zachowań Zdrowotnych (IZZ) autorstwa Zygfryda Juczyńskiego zaliczane do kategorii Prawidłowe Nawyki Żywieniowe (PNŻ). W kategorii tej oceniano spożywanie dużej ilości warzyw i owoców, ograniczenie spożywania tłuszczów zwierzęcych i cukrów, dbanie o prawidłowe odżywianie, unikanie spożywania żywności z konserwantami, soli i silnie solonej żywności oraz jedzenie pieczywa pełnoziarnistego. Twierdzenia opatrzono 5-stopniową skalą Likerta, przybierającą wartości od 1 (prawie nigdy) do 5 (zawsze). Badany mógł uzyskać 6-30 punktów, przy czym im wyższy wynik, tym większe nasilenie deklarowanych zachowań zdrowotnych [8].

Badania miały charakter dobrowolny, indywidualny, anonimowy. Zostały przeprowadzone zgodnie z założeniami Deklaracji Helsińskiej. Respondentów poinformowano o celu i przebiegu badań. Analizy materiału badawczego dokonano przy użyciu pakietu statystycznego STATISTICA 12 i programu Microsoft Office Excel. Przyjęto poziom istotności $p<0,05$, wskazujący na istotne statystycznie różnice bądź zależności. Wykorzystano test $\mathrm{chi}^{2}$.

\section{Wyniki}

Ponad połowa respondentów (53\%) spożywała 3-4 posiłki dziennie. Pozostali spożywali 5 posiłków (35\%) lub 1-2 posiłki (12\%) w ciągu dnia. Przeprowadzone badania nie wykazały istotnego związku pomiędzy liczbą dziennie konsumowanych posiłków a wiekiem $(p=0,99)$ i płcią $(p=0,98)$. Badani będący w związku nieznacznie częściej wskazywali na niedostateczną ilość zjadanych dziennie posiłków w porównaniu z ankietowanymi stanu wolnego, przy czym stwierdzone różnice nie były istotne statystycznie ( $p=0,25)$. Ilości konsumowanych posiłków nie determinowały także miejsce zamieszkania $(p=0,17)$, poziom wykształcenia $(p=0,66)$ i sytuacja materialna $(p=0,24)$. Jednakże zauważono, że ankietowani z terenów wiejskich (47\%), o najniższym wykształceniu, zadowalającej sytuacji materialnej nieznacznie częściej spożywali powyżej 5 posiłków w ciągu dnia w porównaniu z badanymi mieszkającymi w mieście (29\%), ze średnim i wyższym wykształceniem, przeciętną lub złą sytuacją finansową (Tabela 1). 
Tabela 1. Liczba zjadanych dziennie posiłków przez osoby z nowotworem w zależności od zmiennych socjodemograficznych

Table 1. The number of meals eaten per day by people with cancer depending on socio-demographic variables

\begin{tabular}{|c|c|c|c|c|c|c|}
\hline \multirow{3}{*}{ Zmienna/Variable } & \multicolumn{6}{|c|}{$\begin{array}{l}\text { Liczba dziennie spożywanych posiłków/ } \\
\text { Number of meals consumed per day }\end{array}$} \\
\hline & \multicolumn{2}{|c|}{$\begin{array}{l}\text { 1-2 posiłki/ } \\
\text { meals }\end{array}$} & \multicolumn{2}{|c|}{$\begin{array}{l}\text { 3-4 posiłki/ } \\
\text { meals }\end{array}$} & \multicolumn{2}{|c|}{$\begin{array}{l}>5 \text { posiłków/ } \\
\text { meals }\end{array}$} \\
\hline & $\mathrm{n}$ & $\%$ & $\mathrm{n}$ & $\%$ & $\mathrm{n}$ & $\%$ \\
\hline \multicolumn{7}{|c|}{ Wiek/Age } \\
\hline Do 40 lat/Up to 40 years & 4 & 12 & 18 & 55 & 11 & 33 \\
\hline $41-50$ lat/41-50 years & 3 & 11 & 15 & 56 & 9 & 33 \\
\hline $\begin{array}{l}\text { Powyżej } 50 \text { lat/ } \\
\text { Over } 50 \text { years }\end{array}$ & 5 & 12,5 & 20 & 50 & 15 & 37,5 \\
\hline \multicolumn{7}{|c|}{ Analiza statystyczna/Statistical analysis: chi $^{2}=0,26 ; p=0,99$} \\
\hline \multicolumn{7}{|c|}{ Płeć/Sex } \\
\hline Kobiety/Women & 8 & 12 & 37 & 54 & 24 & 34 \\
\hline Mężczyźni/Men & 4 & 13 & 16 & 52 & 11 & 35 \\
\hline \multicolumn{7}{|c|}{ Analiza statystyczna/Statistical analysis: $\mathrm{chi}^{2}=0,05 ; \mathrm{p}=0,98$} \\
\hline \multicolumn{7}{|c|}{ Stan cywilny/Marital status } \\
\hline Wolny/Single & 9 & 16 & 26 & 47 & 20 & 37 \\
\hline W związku/In a relationship & 3 & 7 & 27 & 60 & 15 & 33 \\
\hline \multicolumn{7}{|c|}{ Analiza statystyczna/Statistical analysis: chi $^{2}=2,76 ; p=0,25$} \\
\hline \multicolumn{7}{|c|}{ Miejsce zamieszkania/Place of residence } \\
\hline Miasto/City & 8 & 12 & 39 & 59 & 19 & 29 \\
\hline Wieś/Village & 4 & 12 & 14 & 41 & 16 & 47 \\
\hline \multicolumn{7}{|c|}{ Analiza statystyczna/Statistical analysis: chi ${ }^{2}=3,50 ; p=0,17$} \\
\hline \multicolumn{7}{|c|}{ Wykształcenie/Education } \\
\hline $\begin{array}{l}\text { Podstawowe, zawodowe/ } \\
\text { Basic, vocational }\end{array}$ & 5 & 14 & 16 & 46 & 14 & 40 \\
\hline Średnie/Average & 6 & 12 & 26 & 53 & 17 & 35 \\
\hline Wyższe/Higher & 1 & 6 & 11 & 69 & 4 & 25 \\
\hline \multicolumn{7}{|c|}{ Analiza statystyczna/Statistical analysis: chi $^{2}=2,40 ; p=0,66$} \\
\hline \multicolumn{7}{|c|}{ Sytuacja materialna/Financial situation } \\
\hline $\begin{array}{l}\text { Dobra, bardzo dobra/ } \\
\text { Good, very good }\end{array}$ & 5 & 8 & 34 & 54 & 24 & 38 \\
\hline $\begin{array}{l}\text { Przeciętna, zła/ } \\
\text { Average, bad }\end{array}$ & 7 & 19 & 19 & 51 & 11 & 30 \\
\hline Analiza statystyczn & na/St & stical a & lysis: & ${ }^{2}=2,8$ & $=0,24$ & \\
\hline
\end{tabular}

$\mathrm{n}$ - liczebność/number, \% - odsetek/percentage, p - istotność statystyczna/ statistical significance, chi $^{2}$ - wynik testu $\mathrm{chi}^{2} / c h{ }^{2}$ test results

Źródło: opracowanie własne

Source: author's own analysis

Analiza statystyczna wykazała, że częstotliwości spożywania posiłków przez pacjentów onkologicznych nie determinowały typ nowotworu $(p=0,17)$, czas trwania choroby $(p=0,08)$, czas rozpoznania $(p=0,52)$. Mimo to zaobserwowano, że respondenci z nowotworem łagodnym (40\%), chorujący od roku do 2 lat, a także ci, u których po raz pierwszy rozpoznano nowotwór, nieznacznie częściej spożywali powyżej 5 posiłków dziennie w porównaniu z pozostałymi badanymi (Tabela 2).
Tabela 2. Liczba spożywanych dziennie posiłków w zależności od charakteru choroby

Table 2. The number of meals eaten per day depending on the nature of the disease

\begin{tabular}{|c|c|c|c|c|c|c|}
\hline \multirow{3}{*}{ Zmienna/Variable } & \multicolumn{6}{|c|}{$\begin{array}{l}\text { Liczba dziennie spożywanych posiłków/ } \\
\text { Number of meals consumed per day }\end{array}$} \\
\hline & \multicolumn{2}{|c|}{$\begin{array}{l}\text { 1-2 posiłki/ } \\
\text { meals }\end{array}$} & \multicolumn{2}{|c|}{$\begin{array}{l}\text { 3-4 posiłki/ } \\
\text { meals }\end{array}$} & \multicolumn{2}{|c|}{$\begin{array}{c}>5 \text { posiłki/ } \\
\text { meals }\end{array}$} \\
\hline & $\mathrm{n}$ & $\%$ & $\mathrm{n}$ & $\%$ & $\mathrm{n}$ & $\%$ \\
\hline
\end{tabular}

Typ nowotworu/Type of cancer

\begin{tabular}{|c|c|c|c|c|c|c|}
\hline \multicolumn{7}{|l|}{ Nowotwór miejscowo } \\
\hline $\begin{array}{c}\text { złośliwy/Locally malignant } \\
\text { neoplasm }\end{array}$ & 3 & 25 & 6 & 50 & 3 & 25 \\
\hline $\begin{array}{l}\text { Nowotwór łagodny/Benign } \\
\text { tumor }\end{array}$ & 1 & 2,5 & 23 & 57,5 & 16 & 40 \\
\hline $\begin{array}{l}\text { Nowotwór złośliwy/Mali- } \\
\text { gnant neoplasm }\end{array}$ & 8 & 17 & 24 & 50 & 16 & 33 \\
\hline \multicolumn{7}{|c|}{ Analiza statystyczna/Statistical analysis: $\mathrm{chi}^{2}=6,49 ; \mathrm{p}=0,17$} \\
\hline \multicolumn{7}{|c|}{ Czas trwania choroby/Duration of illness } \\
\hline Do roku/To year & 6 & 27 & 10 & 46 & 6 & 27 \\
\hline 1-2 lata/ $1-2$ years & 2 & 9 & 8 & 36 & 12 & 55 \\
\hline $2-3$ lata/2-3 years & 3 & 9 & 24 & 63 & 11 & 28 \\
\hline $\begin{array}{c}\text { Ponad } 3 \text { lata/More than } \\
3 \text { years }\end{array}$ & 1 & 6 & 11 & 61 & 6 & 33 \\
\hline \multicolumn{7}{|c|}{ Analiza statystyczna/Statistical analysis: chi $^{2}=11,13 ; p=0,08$} \\
\hline \multicolumn{7}{|c|}{ Czas rozpoznania/Time of reconnaissance } \\
\hline $\begin{array}{l}\text { Pierwszy raz rozpoznany/ } \\
\text { For the first time recognized }\end{array}$ & 9 & 11 & 45 & 53 & 31 & 36 \\
\hline Wznowa/Recurrence & 3 & 20 & 8 & 53 & 4 & 27 \\
\hline
\end{tabular}

$\mathrm{n}$ - liczebność/number, \% - odsetek/percentage, p - istotność statystyczna/ statistical significance, $\mathrm{chi}^{2}$ - wynik testu chi $/$ chi test results

Źródło: opracowanie własne

Source: author's own analysis

$Z$ analizy odpowiedzi na pytania wchodzące w skład kategorii PNŻ IZZ wynika, że większość ankietowanych tylko od czasu do czasu dbała o prawidłowe odżywianie (47\%). Respondenci sporadycznie spożywali pieczywo pełnoziarniste $(40 \%)$, ograniczali spożywanie takich produktów jak tłuszcze zwierzęce, cukier (36\%), sól i silnie solna żywność (33\%), a także produktów z konserwantami (33\%). Wskazali za to na częste konsumowanie dużej ilości warzyw i owoców, w tym $26 \%$ - prawie zawsze, $23 \%$ - zawsze. W ogólnej ocenie analizowana próba uzyskała przeciętne rezultaty w kategorii Prawidłowe Nawyki Żywieniowe. Osiągnięty wynik był niższy o 0,51 w porównaniu do rezultatu grupy normalizacyjnej podanej przez Juczyńskiego [8]. Ankietowani deklarowali najlepsze zachowania żywieniowe wobec unikania spożycia soli $(3,44)$, wobec konsumpcji dużej ilości warzyw i owoców $(3,41)$, a także wobec dbania o prawidłowe odżywianie $(3,38)$ (Tabela 3). 
Tabela 3. Rozkład odpowiedzi w kategorii Prawidłowe Nawyki Żywieniowe

Table 3. Distribution of answers in the category Proper Eating Habits

\begin{tabular}{|c|c|c|c|c|c|c|}
\hline Twierdzenie/The claim & $\begin{array}{c}\text { Prawie } \\
\text { nigdy/ } \\
\text { Almost } \\
\text { never } \\
\mathrm{n}\end{array}$ & $\begin{array}{c}\text { Rzadko/ } \\
\text { Rarely } \\
\text { n }\end{array}$ & $\begin{array}{c}\text { Od czasu } \\
\text { do czasu/ } \\
\text { Occasio- } \\
\text { nally } \\
n \\
\end{array}$ & $\begin{array}{c}\text { Prawie } \\
\text { zawsze/ } \\
\text { Almost } \\
\text { always } \\
\mathrm{n}\end{array}$ & $\begin{array}{c}\text { Zawsze/ } \\
\text { Always } \\
\text { n }\end{array}$ & $\begin{array}{l}\text { Średnia/ } \\
\text { Average }\end{array}$ \\
\hline $\begin{array}{l}\text { Jem dużo warzyw, } \\
\text { owoców/l eat a lot of } \\
\text { vegetables, fruit }\end{array}$ & 7 & 17 & 27 & 26 & 23 & 3,41 \\
\hline $\begin{array}{l}\text { Ograniczam spoży- } \\
\text { wanie produktów, jak } \\
\text { tłuszcze zwierzęce, } \\
\text { cukier/l limit con- } \\
\text { sumption of products, } \\
\text { such as animal fats, } \\
\text { sugar }\end{array}$ & 更 & 17 & 36 & 28 & 15 & 2,97 \\
\hline $\begin{array}{l}\text { Dbam o prawidłowe } \\
\text { odżywianie// care } \\
\text { about proper nutrition }\end{array}$ & 2 & 12 & 47 & 24 & 15 & 3,38 \\
\hline $\begin{array}{l}\text { Unikam spożywania } \\
\text { żywności } \\
\text { z konserwantami/ } \\
\text { lavoid eating food } \\
\text { with preservatives }\end{array}$ & 5 & 16 & 33 & 30 & 16 & 2,77 \\
\hline $\begin{array}{l}\text { Unikam soli i silnie } \\
\text { solonej żywności/ } \\
\text { I avoid salt and highly } \\
\text { salted foods }\end{array}$ & 5 & 13 & 33 & 31 & 18 & 3,44 \\
\hline $\begin{array}{l}\text { Jem pieczywo pełno- } \\
\text { ziarnistel/ eat whole } \\
\text { wheat bread }\end{array}$ & 5 & 16 & 40 & 26 & 13 & 3,26 \\
\hline $\begin{array}{c}\text { Ogółem Prawidłowe } \\
\text { Nawyki Żywieniowe/ } \\
\text { Total Proper Eating } \\
\text { Habits }\end{array}$ & \multicolumn{6}{|c|}{$M=3,36 ; M e=3,25 ; Q 1=2,75 ; Q 3=4,00 ; S D=0,85$} \\
\hline
\end{tabular}

M - średnia/average, Me - mediana/median, SD - odchylenie standardowe/ standard deviation, Q1 - dolny kwartyl/bottom quartile, Q3 - górny kwartyl/ top quartile, n- liczebność/numer

Źródło: opracowanie własne

Source: author's own analysis

\section{Dyskusja}

Za jeden z najważniejszych czynników środowiska zewnętrznego wpływający na rozwój i kondycję zdrowotną człowieka uważa się prawidłowe żywienie. Wśród wyznaczników racjonalnego sposobu odżywiania wymieniono prawidłowo zbilansowaną dietę, która dostarcza energii i niezbędnych składników odżywczych, liczbę oraz regularność posiłków, jakość spożywanych produktów. Instytut Żywności i Żywienia (IŻŻ) zaleca spożywanie 5 posiłków dziennie, w tym śniadania, drugiego śniadania, obiadu, podwieczorku i kolacji. Gałaś zaleca, by posiłki w dwóch trzecich składały się z warzyw i owoców, pełnoziarnistego zboża, roślin strączkowych. Pozostałą część stanowić powinny produkty zwierzęcego pochodzenia [9]. Ankietowani z autorskiej analizy posilali się przeważnie 3-4 razy dziennie (53\%). Zalecaną przez IŻŻ liczbę 5 posiłków deklarowało 35\% badanych. Badania nie wykazały istotnego związku między liczbą dziennie konsumowanych posiłków a zmiennymi socjodemograficznymi i typem nowotworu, czasem trwania oraz rozpoznania choroby.

„Liczne badania potwierdzają wpływ diety na powstawanie oraz rozwój choroby nowotworowej, dlatego istotna wydaje się profilaktyka chorób nowotworowych poprzez szerzenie wiedzy na temat właściwych zachowań zdrowotnych, w tym również odpowiednich nawyków żywieniowych" [7]. Rozwój nowotworów dietozależnych determinują wysoka podaż energii, nadmierna masa ciała, duże spożycie tłuszczów, czerwonego mięsa, soli kuchennej, niedobór błonnika pokarmowego, warzyw, owoców, produktów nabiałowych [10]. Czeczelewska i wsp. donoszą, że zachowanie prawidłowej masy ciała, ograniczenie wartości energetycznej diety, konsumpcji cukrów prostych i alkoholu, przy jednoczesnym zwiększeniu spożycia warzyw, owoców i regularna aktywność fizyczna redukują o 50\% ryzyko wystąpienia raka piersi [11]. Międzynarodowa Agencja Badań Nowotworów informuje, że niewłaściwa dieta odpowiada za rozwój raka piersi [12]. Właściwości kancerogenne przypisuje się także substancjom dodawanym do żywności i zanieczyszczeniom technicznym oraz środowiskowym produktów [13]. Nawyki żywieniowe są ściśle związane z ryzykiem zachorowania na pewne typy nowotworów, ale i zapobieganiem ich rozwojowi i wspomaganiem leczenia [9]. Właściwości prewencyjne chorób nowotworowych przypisuje się zastępowaniu kwasów tłuszczowych nasyconych pochodzenia zwierzęcego tłuszczami roślinnymi, ograniczeniu konsumpcji tłustych, słodkich, słonych produktów, zwiększeniu spożycia warzyw i owoców, utrzymaniu prawidłowej masy ciała [14].

Otyłość i nadwaga są niezależnymi czynnikami ryzyka rozwoju nowotworów złośliwych, które rośnie przy wartości współczynnika BMI wynoszącej 22-23kg/m². W związku z powyższym zaleca się utrzymywanie poziomu BMI możliwie blisko granicy normy [1]. Potwierdzeniem tej zależności są doniesienia Kałędkiewicz i wsp., zdaniem których nadmiar tkanki tłuszczowej stanowi czynnik etiologiczny dla raka jelita grubego, trzustki, sutka, macicy, prostaty, nerek, odbytu [15]. Ponadto dieta opierająca się na produktach spożywczych o wysokim indeksie glikemicznym (IG > 70) istotnie zwiększa ryzyko zachorowania na wiele nowotworów [16], m.in. raka jajnika, macicy, jamy ustnej, przełyku, krtani [7]. Częsta konsumpcja przekąsek, które zawierają węglowodany przetworzone o wysokim IG, o około 1,3 razy podnosi ryzyko rozwoju nowotworu [17].

Adamowicz określił ogólny poziom realizacji zachowań sprzyjających zdrowiu wśród chorych na raka 
płuca jako niski. Stwierdził, iż społeczeństwo polskie nie przykłada wagi do Prawidłowych Nawyków Żywieniowych i innych zachowań zdrowotnych, co zdaniem badacza wynika z powszechnego obecnie zbyt swobodnego stylu życia. Zaobserwował, że zalecenia dietetyczne częściej przestrzegane były przez kobiety [18]. Kiciak i wsp. w wyniku analizy nawyków żywieniowych ankietowanych pacjentów onkologicznych stwierdzili liczne nieprawidłowości w zakresie doboru i częstotliwości konsumpcji poszczególnych produktów spożywczych. Nieprawidłowe nawyki żywieniowe skutkują zaburzeniami masy ciała, które wpływają na rozwój choroby nowotworowej. Badacze postulują konieczność podjęcia działań promocyjnych odnośnie właściwych zachowań żywieniowych w grupie osób cierpiących na nowotwór [19]. Misiak podkreśla, że bardzo ważne jest spożycie przez pacjentów onkologicznych wystarczającej ilości pokarmów, które zapewniają odpowiednią ilość energii i białka. Jest to wielce istotne podczas procesu leczenia, następnie rekonwalescencji oraz odbudowy zniszczonego przez nowotwór organizmu [20]. Ankietowane w badaniach Kurowskiej i Kalawskiej prezentowały przeciętny poziom Prawidłowych Nawyków Żywieniowych. Dbały o prawidłowe odżywianie, w tym spożywały dużo warzyw i owoców, lecz problematyczne było ograniczenie spożycia tłuszczów zwierzęcych, cukru. Najwyższe wyniki w obrębie Prawidłowych Nawyków Żywieniowych osiągnęły respondentki o wyższym wykształceniu, pochodzące ze wsi, w rodzinie których nie występowały przypadki choroby nowotworowej [21]. W badaniach Dydjow-Bendek i Ejsmont w żywieniu analizowanej grupy wykryto czynniki kancerogenne w postaci częstej konsumpcji alkoholu, chipsów, słodyczy, częste smażenie potraw, niedostateczną ilość błonnika. W diecie badanych zauważono także elementy antykancerogenne, jak konsumpcja dużej ilości warzyw i owoców, nabiału, rzadkie spożycie fast food, wędzonych przetworów mięsnych [22]. Ankietowane na podstawie IZZ przez Kurowską i Adamczyk chore na raka piersi otrzymały najniższe oceny w zakresie Prawidłowe Nawyki Żywieniowe. W obrębie tej kategorii „Najwyżej oceniono dbałość o prawidłowe odżywianie $(3,69)$ oraz jedzenie dużej ilości warzyw i owoców $(3,78)$, najniżej - unikanie żywności z konserwantami $(3,33)$ i spożywanie pieczywa pełnoziarnistego (2,99)" [23]. Także ankietowani przez Bojakowską i wsp. uzyskali niskie wyniki w kategorii Prawidłowe Nawyki Żywieniowe. Badane przed zdiagnozowaniem choroby nowotworowej osiągnęły wynik 2,68, zaś po zdiagnozowaniu raka piersi wynosił on już 4,38 [24]. W badaniach własnych w ogólnej ocenie analizowana próba uzyskała przeciętne rezultaty w kategorii Prawidłowe Nawyki Ży- wieniowe, przy czym średnią oszacowano na 3,36. Ankietowani deklarowali najlepsze zachowania żywieniowe wobec unikania spożycia soli $(3,44)$, wobec konsumpcji dużej ilości warzyw i owoców $(3,41)$, a także wobec dbania o prawidłowe odżywianie $(3,38)$.

Bardzo cennym źródłem substancji przeciwnowotworowych są warzywa kapustne. Największe znaczenie chemioprewencyjne mają wszystkie odmiany kapusty, jak biała, pekińska, czerwona czy włoska, brokuły, kalafior, rzodkiewka, brukselka oraz rzepak [25]. Ich spożycie zmniejsza zapadalność na nowotwory, w tym szczególnie jelita grubego, piersi, płuc [26]. Boeing i wsp. wskazują na obniżenie prawdopodobieństwa zachorowania na nowotwór złośliwy na skutek wzrostu spożycia warzyw. Donoszą, że dostarczanie $50 \mathrm{~g}$ warzyw niskoskrobiowych dziennie obniża ryzyko nowotworu jamy ustnej, krtani i gardła o 28\% [27]. Owoce mają podobne właściwości, gdyż dzienne spożycie $100 \mathrm{~g}$ zmniejsza ryzyko zachorowania na raka gardła, jamy ustnej, płuca oraz krtani o 18\% [28]. Jednakże największe antynowotworowe właściwości przypisuje się cytrusom, borówkom, truskawkom, winogronom. Beliveau i Gingars zalecają, aby osoby po przejściu choroby nowotworowej zwiększyły spożycie warzyw oraz owoców, jedząc przynajmniej 5 porcji dziennie, gdyż dostarczają wówczas koniecznych w profilaktyce nowotworowej witamin antyoksydacyjnych [29, 30]. Korzystną rolę w profilaktyce przeciwnowotworowej odgrywają żółte i pomarańczowe warzywa i owoce, jak marchew, dynia, papryka, pomidory, melony, pomarańcze, z racji dużej zawartości karotenoidów. Wykazują ujemną korelację z rozwojem nowotworów płuca, przełyku, krtani czy jamy ustnej [31]. Prawie połowa ankietowanych przez Kiciak i wsp. chorych na nowotwór przynajmniej w 2 posiłkach dziennie konsumowała warzywa i owoce. Ponad jedna piąta deklarowała rzadsze ich spożycie [19]. W autorskiej analizie respondenci wskazali na częste konsumowanie dużej ilości warzyw i owoców, w tym 26\% - prawie zawsze, $23 \%$ - zawsze.

Tylko 5\% ankietowanych przez Kiciak i wsp. pacjentów onkologicznych nie spożywało potraw smażonych [19]. Dowiedziono, że zwiększone spożycie tłuszczów podwyższa ryzyko zachorowania na nowotwór piersi, okrężnicy, prostaty [32]. Zaobserwowano aż o 19\% wzrost ryzyka rozwoju raka piersi w wyniku konsumpcji tłuszczów bogatych w kwasy tłuszczowe nasycone, zawarte głównie w czerwonym mięsie i nabiale [33]. Według Malczyk i Majkrzak „W całodziennej diecie należy ograniczyć podaż olejów roślinnych będących źródłem kwasów tłuszczowych z rodziny n-6 oraz tłuszczów zawierających kwasy tłuszczowe nasycone" [34]. Analizowana w badaniach własnych próba sporadycznie 
ograniczała spożywanie tłuszczów zwierzęcych. Ponadto respondenci osiągnęli niezadowalające wyniki w tej kategorii, które oszacowano na 2,97.

Istotne właściwości antynowotworowe mają produkty pełnoziarniste bogate w witaminy, błonnik pokarmowy, składniki mineralne. Są jednym z czynników ochraniających organizm przed nowotworami odbytu, jelita grubego, żołądka [15]. W badaniach Kiciak i wsp. grube kasze i ciemne pieczywo były rzadko spożywane. Respondenci wskazywali najczęściej odpowiedzi: raz na 2 tygodnie, w ogóle, raz w miesiącu [19]. Respondenci w badaniach własnych przeważnie sporadycznie spożywali pieczywo pełnoziarniste (40\%), a wynik średni oszacowano na 3,26.

Polacy wykazują ponadnormatywne spożycie soli, które szacuje się na 13 g. Wartość ta jest jedną z najwyższych w Europie. Według zaleceń Światowej Organizacji Zdrowia dzienne spożycie sodu nie powinno przekraczać $2 \mathrm{~g}$, tj. $5 \mathrm{~g}$ soli kuchennej [35]. Kłosiewicz-Latoszek doradza, aby nie dosalać potraw, ograniczyć konsumpcję produktów konserwowanych, przetworzonych, które zawierają dużą ilość soli na rzecz świeżych produktów [14]. Zadowalające są rezultaty badań własnych dotyczące spożycia soli. Badani uzyskali wynik 3,44 przy twierdzeniu o unikaniu soli i silnie solonej żywności, a 31\% prawie zawsze stosowało się do tego zalecenia.

„Mimo nasilającego się społecznego przekonania, że dbanie o kondycję zdrowotną jest ważne, deklaracje Polaków dotyczące troski o stan własnego zdrowia nie korelują dodatnio z praktykami zdrowotnymi. W modyfikowaniu zachowań związanych ze zdrowiem konieczne jest pogłębienie wiedzy na temat mechanizmów odpowiedzialnych za zmianę zachowań" [36].

\section{Wnioski}

1. Badania nie wykazały istotnego związku między liczbą dziennie konsumowanych posiłków a zmiennymi socjodemograficznymi, typem nowotworu, czasem trwania oraz rozpoznania choroby.

2. Zalecaną przez IŻŻ liczbę 5 posiłków deklarowała blisko jedna trzecia badanych. Ankietowani posilali się przeważnie 3-4 razy dziennie.

3. W ogólnej ocenie analizowana próba uzyskała przeciętne rezultaty w kategorii Prawidłowe Nawyki Żywieniowe. Ankietowani deklarowali najlepsze zachowaniażywieniowe wobecunikaniaspożyciasoli, wobec konsumpcji dużej ilości warzyw i owoców, a także wobec dbania o prawidłowe odżywianie.

\section{Piśmiennictwo}

1. World Cancer Research Fund, American Institute for Cancer Research. Food, Nutrition, Physical Activity and the Prevention of Cancer: a Global Perspective. Washington: AICR; 2007. 72, 212-213.

2. Demark-Wahnefried W, Jones LW, Snyder DC et al. Daughters and Mothers Against Breast Cancer (DAMES): Main outcomes of a randomized controlled trial of weight loss in overweight mothers with breast cancer and their overweight daughters. Cancer. 2014; 120: 2522-2534.

3. Dudziak K, Regulska-llow B. Znaczenie ładunku glikemicznego diety w rozwoju chorób nowotworowych. Post Hig Med Dośw. 2013; 67: 449-462.

4. Klimczak A, Malinowska K, Kubiak K. Choroby nowotworowe a żywienie. Pol Merk Lek. 2009; 27(159): 242-244.

5. Nalewaj J, Markowska J. Żywienie a choroby nowotworowe. Prz Urolog. 2005; 6(1): 15-16.

6. Gawęcki J, Hryniewiecki L. Żywienie człowieka. Podstawy nauki o żywieniu. Warszawa: PWN; 1998.

7. Pudło H, Respondek M, Szefczyk-Polowczyk L et al. Wpływ diety na występowanie chorób nowotworowych. J Educ Health Sport. 2015; 5(9): 549-558.

8. Juczyński Z. Inwentarz Zachowań Zdrowotnych. W: Juczyński Z (red.). Narzędzia pomiaru w promocji i psychologii zdrowia. Warszawa: Pracownia Testów Psychologicznych Polskiego Towarzystwa Psychologicznego; 2012. 110-116.

9. Gałaś A. Zwyczaje żywieniowe jako element zapobiegania chorobom nowotworowym jelita grubego - trudności i wyzwania. Probl Hig Epidemiol. 2009; 90(4): 451-458.

10. Kardasz M, Pawłowska D. Rola składników odżywczych oraz innych substancji w powstawaniu nowotworów. Nowa Med. 2008; 2: 7-14.

11. Czeczelewska E, Kościańska B, Janczaruk M et al. Wiedza młodych kobiet na temat roli czynnika dietetycznego w zapobieganiu raka piersi. Prz Med Uniw Rzesz. 2011; 2: 212-223.

12. Janssens J, Vandeloo M. Rak piersi: bezpośrednie i pośrednie czynniki ryzyka związane z wiekiem i stylem życia. J Oncol. 2009; 59(3): 159-167.

13. Timbrell J. Paradoks trucizn. Substancje chemiczne przyjazne i wrogie. Warszawa: WNT; 2008.

14. Kłosiewicz-Latoszek L. Zalecenia żywieniowe w prewencji chorób przewlekłych. Probl Hig Epidemiol. 2009; 90(4): 447-450.

15. Kałędkiewicz E, Doboszyńska A. Wpływ sposobu żywienia na wznowę chorób nowotworowych. Forum Med Rodz. 2014; 8(6): 310-319.

16. Mulholland HG, Murray LJ, Cardwell CR et al. Dietary glycaemic index, glycaemic load and breast cancer risk: a systematic review and meta-analysis. Brit J Cancer. 2008; 99: 1170-1175.

17. Sieri S, Pala V, Brighenti F, et al. Dietary glycemic index, glycemic load, and the risk of breast cancer in an Italian prospective cohort study. Am J Clin Nutr. 2007; 86(4): 1160-1166.

18. Adamowicz K. Ocena wiedzy w zakresie chorób nowotworowych oraz wybranych zachowań sprzyjających zdrowiu wśród chorych na zaawansowanego, przerzutowego raka płuca w trakcie chemioterapii. Psychoonkologia. 2016; 20(2): 84-89.

19. Kiciak A, Całyniuk B, Grochowska-Niedworok E et al. Wybrane zachowania żywieniowe osób z chorobą nowotworową. Hygeia Public Health. 2012; 47(3): 354-359.

20. Misiak M. Wyniszczenie nowotworowe. Współcz Onkol. 2003; 7(5): 381-388.

21. Kurowska K, Kalawska H. Zachowania zdrowotne a umiejscowienie kontroli zdrowia u kobiet po mastektomii. Curr Gynecol Oncol. 2013; 11(2): 115-124.

22. Dydjow-Bendek D, Ejsmont J. Sposób żywienia a ryzyko wystąpienia chorób nowotworowych. Probl Hig Epidemiol. 2010; 91(4): 618-622.

23. Kurowska K, Adamczyk I. Rola wsparcia i zachowań zdrowotnych w zmaganiu się kobiet z rakiem piersi. Curr Gynecol Oncol. 2014; 12(4): 278-289. 
24. Bojakowska U, Kalinowski P, Kowalska ME. Evaluation of selected health behaviors before and after the diagnosis among women with breast cancer based on the Health-Related Behaviour Inventory ( $\mathrm{HBI}$ ) questionnaire developed by Juczyński - preliminary study. J Educ Health Sport. 2016; 6(5): 29-37.

25. Grzybowska-Szwejda J. Antykancerogenne składniki warzyw kapustnych i ich znaczenie w profilaktyce chorób nowotworowych. Bromat Chem Toksykol. 2011; 44(4): 1039-1046.

26. Kusznierewicz B, Piasek A, Lewandowska J et al. Właściwości przeciwnowotworowe kapusty białej. Żywn Nauk Technol Jakość. 2007; 6(55): 20-34.

27. Boeing H, Dietrich T, Hoffmann K. Intake of fruits and vegetables and risk of cancer of the upper aero-digestive tract. Cancer Causes Control. 2006; 17: 957-969.

28. Maserejian N, Giovannucci E, Rosner B. Prospective study of fruits and vegetables and risk of oral premalignant lesions in men. Am J Epidemiol. 2006; 164: 556-566.

29. Beliveau R, Gingras D. Dieta w walce z rakiem - profilaktyka i wspomaganie terapii przez odżywianie. Warszawa: Delta W-Z; 2009.

30. Krukowska M, Olejniczak D. Ocena wiedzy studentów na temat czynników ryzyka i profilaktyki nowotworów płuc. Med Rodz. 2013; 4: 143-148.

31. Putowski M, Piróg M, Padał O et al. Wybrane składniki diety w profilaktyce najczęściej występujących nowotworów w Polsce - przegląd aktualnych wyników badań. J Educ Health Sport. 2015; 5(8): 73-84.

32. Cichosz G, Czeczot H. Rzekomo zdrowe tłuszcze roślinne. Pol Merk Lek. 2011; 31(184): 239-243.
33. Beliveau R, Gingras D. Dieta w walce z chorobami. Warszawa: Delta; 2011.

34. Malczyk E, Majkrzak Ż. Żywieniowe czynniki ryzyka rozwoju raka piersi. Probl Hig Epidemiol. 2015; 96(1): 67-76.

35. Szponar L, Sekuła W, Rychlik E et al. Badania indywidualnego spożycia żywności i stanu odżywienia w gospodarstwach domowych. Warszawa: Instytut Żywności i Żywienia; 2003.

36. Gruszczyńska M, Bąk-Sosnowska M, Plinta R. Zachowania zdrowotne jako istotny element aktywności życiowej człowieka. Stosunek Polaków do własnego zdrowia. Hygeia Public Health. 2015; 50(4): 558-565.

Artykuł przyjęty do redakcji: 22.04.2017

Artykuł przyjęty do publikacji: 01.08.2017

Źródło finansowania: Praca nie jest finansowana z żadnego źródła. Konflikt interesów: Autorzy deklarują brak konfliktu interesów.

\section{Adres do korespondencji:}

Olga Dąbska

ul. Stanisława Staszica 4-6

20-081 Lublin

tel.: 814486792

e-mail: olga49a@wp.pl

Zakład Patologii i Rehabilitacji Mowy, Wydział Nauk o Zdrowiu

Uniwersytet Medyczny w Lublinie 